\title{
ANALISIS OVERLAY TERHADAP POTENSI PAJAK DAERAH SEBAGAI SUMBER PENDAPATAN ASLI DAERAH (PAD) KOTA BAUBAU
}

\author{
Muhammad Rais R. \\ Program Studi Akuntansi, Fakultas Ekonomi \\ Universitas Muhammadiyah Buton, Baubau, Indonesia \\ e-mail: raismuhamad000@ gmail.com
}

\begin{abstract}
ABSTRAK
Penelitian ini bertujuan untuk mengetahui potensi pajak daerah sebagai sumber Pendapatan Asli Daerah (PAD) kota Baubau dengan menggunakan analisis overlay. Metode pengumpulan data yang digunakan adalah wawancara dan studi dokumen. Data analisis dengan analisis overlay.Hasil penelitian menunjukkan pertumbuhan dan kontribusi dilakukan matrik berdasarkan berdasarkan analisis overlay tahun 2014-2016. Untuk tahun 2014 yang masuk kategori prima yaitu pajak hotel, pajak restoran, pajak reklame, pajak penerangan jalan, bea perolehan hak atas tanah dan bangunan dan pajak bumi dan bangunan (PBB). Dan kategori berkembang yaitu pajak hiburan dan pajak mineral bukan logam dan batuan. Sedangkan tahun 2015 yang masuk kategori prima yaitu pajak hotel, pajak restoran, pajak reklame, pajak hiburan, pajak penerangan jalan dan pajak bumi dan bangunan (PBB). Dan kategori berkembang yaitu pajak parkiran. Dan kategori terbelakang yaitu pajak mineral bukan logam dan batuan. Dan kategori potensial yaitu bea perolehan hak atas tanah dan bangunan. Sedangkan untuk tahun 2016 yang masuk kategori prima yaitu pajak hotel, pajak restoran, pajak reklame, pajak penerangan jalan, bea perolehan hak atas tanah dan bangunan dan pajak bumi dan bangunan (PBB). Dan kategori berkembang yaitu pajak parkir sedangkan kategori terbelakang yaitu pajak mineral bukan logam dan batuan karena pertumbuhan dan kontribusi $\leq 1$.
\end{abstract}

\section{Kata Kunci : Overlay, Pajak Daerah, Pendapatan Asli Daerah}

\begin{abstract}
This study aims to determine the potential of local taxes as a source of local revenue (PAD) Baubau city by using overlay analysis. Data collection methods used were interviews and document studies. Data analysis with overlay analysis.The results showed that growth and contribution were based on matrix based on overlay analysis of 2014-2016. For the year 2014 which entered the prime category of hotel taxes, restaurant taxes, advertisement taxes, street lighting taxes, land and building acquisition fees and land and building $\operatorname{tax}(P B B)$. And the developing category of entertainment taxes and non-metallic mineral and rock taxes. While the year 2015 which entered the prime category of hotel tax, restaurant tax, advertisement tax, entertainment tax, street lighting tax and land and building tax $(P B B)$. And the developing category of parking tax.And the backward category of nonmetallic mineral and rock taxes. And the potential category is the duty of acquisition of land and building rights. While for the year 2016 which entered the prime category of hotel taxes, restaurant taxes, advertisement taxes, street lighting taxes, land and building acquisition fees and land and building tax $(P B B)$. And the developing category of parking tax whereas the underdeveloped category is nonmetallic mineral taxes and rocks due to growth and contribution $\leq 1$.
\end{abstract}

Keywords: Overlay, Local Taxes, Local Revenue 


\section{PENDAHULUAN}

Dalam rangka penyelenggaraan otonomi daerah, pelimpahan dan penyerahan wewenang serta tugas dan urusan pemerintahan pusat kepada daerah secara nyata dan bertanggung jawab harus diikuti dengan peraturan, pembagian dan pemanfaatan sumber daya nasional secara adil dan merata, termasuk didalamnya perimbangan keuangan antara pemerintah pusat dan daerah. Keyakinan pemerintah dalam mewujudkan pembangunan nasional dengan otonomi daerah adalah dengan dikeluarkannya undang-undang No. 23 tahun 2014 tentang pemerintah daerah dan undang-undang No. 33 tahun 2004 tentang perimbangan keuangan antara pemerintah pusat dan daerah serta undang-undang No. 28 tahun 2009 tentang pajak daerah dan retribusi daerah setelah dimana didalam undang-undang No 28 tahun 2009 pada bagian ke 16 pasal 77 tentang PBB dan bagian ke 17 pasal 85 tentang BPHTB pemerintah telah memberikan kewenangan kepada pemerintah daerah untuk mengelola PBB-P2 dan BPHTB dimasing-masing daerah dimana pelaksanaannya paling lambat pada tahun 2014.

Realisasi pelaksanaan otonomi daerah memerlukan sumber-sumber penerimaan daerah yang diharapkan dan diupayakan dapat menjadi penyangga utama dalam membiayai kegiatan pembangunan di daerah. Pemerintah daerah harus dapat mengupayakan peningkatan penerimaan yang berasal dari daerah sendiri sehingga akan memperbesar tersedianya keuangan daerah yang dapat digunakan untuk berbagai kegiatan pembangunan daerah. Oleh karena itu, pemerintah harus dapat cepat mengidentifikasi sektor-sektor potensial sebagai motor penggerak pembangunan daerah, terutama melalui upaya pengembangan potensi Pendapatan Asli Daerah (PAD). [1]

Dalam upaya menciptakan kemandirian daerah, Pendapatan Asli Daerah (PAD) menjadi faktor yang sangat penting dimana PAD akan menjadi sumber dana dari daerah sendiri [2]. Namun demikian, realitas menunjukkan bahwa PAD hanya mampu membiayai belanja pemerintah daerah paling tinggi sebesar 20\%. [3]

LPEM-FEUI menyatakan bahwa untuk melihat kesiapan pemerintah daerah dalam menghadapi otonomi daerah khususnya di bidang keuangan, diukur dari seberapa jauh kemampuan pembiayaan urusan bila didanai sepenuhnya oleh Pendapatan Asli Daerah (PAD) dan Dana Bagi Hasil (DBH) [4]. Menurut UU No. 33 tahun 2004 tentang Perimbangan Keuangan antara Pemerintah Pusat dan Pemerintah Daerah, komponen pendapatan asli daerah (PAD) terdiri dari pajak daerah, retribusi daerah, hasil pengelolaan kekayaan daerah yang dipisahkan, dan lain-lain PAD yang sah [5]. Empat komponen 
sumber PAD tersebut diharapkan dapat memberikan kontribusi yang positif untuk peningkatan PAD.Kota Baubau merupakan salah satu kota yang terletak di propinsi Sulawesi Tenggara. Kota Baubau sebagai salah satu kota yang diberi hak otonomi atas daerahnya masing-masing untuk mengatur rumah tangganya sendiri guna melaksanakan pembangunan. Pemerintah kota Baubau dan warganya diharapkan mampu bekerjasama dalam mengelola dan memaksimalkan potensi sumber ekonomi untuk memaksimalkan pendapatan daerahnya. Potensi yang dapat dimaksimalkan Kota Baubau yang merupakan sumber pendapatan asli daerah (PAD) adalah Pajak daerah yang terdiri dari pajak Kota yaitu pajak hotel, pajak restoran, pajak hiburan, pajak reklame, pajak penerangan jalan, pajak mineral bukan logam dan batuan, pajak parkir, pajak air tanah, pajak sarang burung walet, pajak bumi dan bangunan perdesaan dan perkotaan, bea perolehan hak atas tanah dan bangunan, Retribusi daerah yang terdiri dari retribusi jasa umum, retribusi jasa usaha, dan retribusi perizinan tertentu, serta lain-lain PAD yang sah yang terdiri dari hasil penjualan kekayaan daerah yang tidak dipisahkan, jasa giro, pendapatan bunga, keuntungan selisih nilai tukar rupiah terhadap mata uang asing, dan komisi, potongan, ataupun bentuk lain sebagai akibat dari penjualan dan/atau pengadaan barang dan/atau jasa oleh daerah harus dioptimalkan dalam rangka mendukung pelaksanaan otonomi daerah. Besarnya penerimaan yang berasal dari daerah akan mempengaruhi besarnya laju pertumbuhan pendapatan asli daerah.

Untuk lebih meningkatkan dan mengoptimalkan pendapatan asli daerah, maka perlu dilakukan upaya-upaya ekstensifikasi terhadap sumber-sumber pendapatan asli daerah Kota Baubau disamping itu perlu juga dilakukan perencanaan yang komprehensif dalam penganggaran keuangan daerah agar rencana pembangunan selaras dengan pengembangan Kota Baubau. Untuk mengetahui jenis pajak daerah yang potensial diperlukan identifikasi atau klasifikasi kondisi yang didasarkan pada jumlah serta perkembangan setiap jenis Pendapatan Asli Daerah (PAD). Identifikasi ini dilakukan dengan cara mematrik antara kontribusi penerimaan dan pertumbuhan penerimaan. Teknik ini sering disebut dengan analisis overlay. Dengan teknik ini akan diketahui jenis pajak daerah mana yang potensial, sehingga dapat membantu dalam melakukan perencanaan.

Kontribusi adalah besaran sumbangan yang diberikan atas sebuah kegiatan yang dilaksanakan [6]. Upaya untuk meningkatkan pendapatan asli daerah dapat dilakukan pemerintah daerah melalui peningkatan pengelolaan pemungutan pajak daerah yang baik sehingga dapat mengoptimalkan penerimaan pajak daerah dan dapat meningkatkan 
Pendapatan Asli Daerah itu sendiri. Apabila PAD meningkat dan mampu membiayai pemerintahan dan pembangunan di daerah, maka ketergantungan keuangan kepada pemerintah pusat akan semakin berkurang [7]. Dalam penelitian ini akan dilakukan analisis mengenai perkembangan dan laju pertumbuhan Pendapatan Asli Daerah dan Pajak Hotel.

Teknik overlay merupakan pendekatan tata guna lahan/landscape. Analisis overlay ini juga dimaksudkan untuk melihat deskripsi kegiatan ekonomi yang potensial berdasarkan kriteria pertumbuhan dan kriteria kontribusi. Teknik overlay ini dibentuk melalui penggunaan secara tumpang tindih (seri) suatu peta yang masing-masing mewakili faktor penting lingkungan/ lahan.Tujuan dan manfaat teknik analisis overlay ini untuk melihat deskripsi kegiatan ekonomi yang potensial berdasarkan pertumbuhan dan kriteria kontribusi. [8]

Analisis Overlay dimaksud adalah untuk melihat deskripsi kegiatan jenis pajak daerah yang potensial berdasarkan kriteria pertumbuhan dan kriteria kontribusi. Untuk mengetahui jenis pajak daerah diperlukan identifikasi atau klasifikasi kondisi yang didasarkan pada jumlah serta perkembangan setiap jenis Pendapatan Asli Daerah (PAD). Identifikasi ini dilakukan dengan cara mematrik antara komposisi penerimaan dan pertumbuhan penerimaan.

\section{METODE PENELITIAN}

Jenis data yang digunakan dalam penelitian ini adalah data kualitatif dan kuantitatif. Data kualitatif adalah data-data yang disajikan dalam bentuk uraian terdiri dari kumpulan data non angka [9]. Data kuantitatif adalah jenis data yang dapat diukur atau dihitung secara langsung, yang berupa informasi atau penjelasan yang dinyatakan dengan bilangan atau berbentuk angka [10] .

Populasi adalah keseluruhan kelompok orang, peristiwa, atau hal yang ingin peneliti investigasi [11]. Sampel terdiri atas sejumlah anggota yang dipilih dari populasi [11] Populasi dalam penelitian ini adalah laporan pajak daerah dan Pendapatan Asli Daerah (PAD) kota Baubau.Sampel dalam penelitian ini adalah laporan laporan pajak daerah dan Pendapatan Asli Daerah (PAD) kota Baubau tahun 2014-2016.

Metode pengumpulan data yang relevan dengan penganalisaan masalah, yaitu penelitian lapangan dan kepustakaan. Penelitian lapangan (field research) dilakukan dengan pengamatan secara langsung melalui observasi dan wawancara pada bagian perusahaan, 
khususnya bagian keuangan, serta sejumlah informasi yang terkait, untuk mendapatkan informasi yang akurat dan lengkap yang berhubungan dengan penulisan ini. Penelitian kepustakaan (library research) penulis menggunakan beberapa teori dari literatur-literatur yang berhubungan dengan masalah yang akan dibahas. [12]

\section{Metode Analisis Data}

Untuk menjawab pertanyaan penelitian yang telah diajukan, maka teknik analisis data yang digunakan adalah analisis overlay [13]. Adapun tahapan yang digunakan adalah sebagai berikut:

1. Analisis pertumbuhan pajak daerah

Untuk mengetahui tingkat pertumbuhan masing-masing jenis pajak daerah digunakan rumus :

$$
\mathrm{g} X i=\frac{\mathrm{Xit}-\mathrm{Xi}(\mathrm{t}-1)}{\mathrm{Xi}(\mathrm{t}-1)} \times 100 \%
$$

Dimana :

$\mathrm{gXi}=$ Pertumbuhan pajak daerah jenis $\mathrm{i}$

$\mathrm{Xit}=$ Jumlah jenis pajak daerah tahun ke $\mathrm{t}$

$\mathrm{Xi}(\mathrm{t}-1)=$ Jenis pajak daerah tahun ke $\mathrm{t}-1$

2. Analisis kontribusi pajak daerah terhadap Pendapatan Asli Daerah (PAD)

Untuk mengetahui kontribusi masing-masing jenis pajak daerah digunakan rumus:

$\mathrm{w} X i=\frac{\mathrm{Xi}}{\mathrm{X}} \mathrm{x} 100 \%$

Dimana :

$w X i=$ Kontribusi pajak daerah jenis $\mathrm{i}$

$\mathrm{Xi}=$ Jumlah pajak daerah jenis $\mathrm{i}$

$\mathrm{X}=$ Total pajak daerah

3. Analisis overlay (Klasifikasi Pajak Daerah).

Untuk mengetahui jenis pajak daerah diperlukan identifikasi atau klasifikasi kondisi yang didasarkan pada jumlah serta perkembangan setiap jenis Pendapatan Asli Daerah (PAD). Identifikasi ini dilakukan dengan cara mematrik antara komposisi penerimaan 
dan pertumbuhan penerimaan. Secara tabel matrik komposisi penerimaan dan pertumbuhan penerimaan jenis pajak daerah dapat dilihat sebagai berikut :

Tabel 1.Matrik Komposisi Penerimaan dan Pertumbuhan Penerimaan Jenis Pajak Daerah

\begin{tabular}{|c|c|c|}
\hline Pertunbuhan & wXi $\geq \mathbf{1}$ (tinggi) & $\mathbf{g X i}<\mathbf{1}$ (rendah) \\
\hline $\mathrm{wXi} \geq 1$ (tinggi) & Prima & Berkembang \\
\hline $\mathrm{gXi}<1$ (rendah) & Potensial & Terbelakang \\
\hline
\end{tabular}

Ket :

$w X i=$ Kontribusi pajak daerah jenis $\mathrm{i}$

$\mathrm{gXi}=$ Pertumbuhan pajak daerah jenis $\mathrm{i}$

\section{HASIL DAN PEMBAHASAN}

a. Hasil Penelitian

Penerimaan Pendapatan Asli Daerah (PAD) Kota Baubau Tahun 2014-2016

Tabel 2. Penerimaan Pendapatan Asli Daerah (PAD) Kota Baubau Tahun 2014-2016

\begin{tabular}{|l|c|r|r|r|r|c|}
\hline No & $\begin{array}{c}\text { Tah } \\
\text { un }\end{array}$ & Pajak Daerah & $\begin{array}{c}\text { Retribusi } \\
\text { Daerah }\end{array}$ & $\begin{array}{c}\text { Hasil } \\
\text { pengolahan } \\
\text { kekayaan daerah } \\
\text { yang dipisahkan }\end{array}$ & $\begin{array}{c}\text { Lain-lain } \\
\text { pendapatan } \\
\text { daerah yang } \\
\text { sah }\end{array}$ & Total PAD \\
\hline 1 & 2014 & 11.438 .566 .186 & 29.106 .576 .889 & 2.674 .592 .706 & 12.830 .749 .408 & 56.050 .485 .189 \\
\hline 2 & 2015 & 13.389 .629 .039 & 3.495 .338 .250 & 2.344 .173 .608 & 17.251 .831 .086 & 36.430 .971 .983 \\
\hline 3 & 2016 & 18.387 .214 .641 & 4.584 .476 .170 & 4.604 .692 .565 & 10.579 .196 .306 & 43.540 .205 .382 \\
\hline \multicolumn{7}{|c|}{ Sumber: Dinas Pendapatan Daerah Kota Baubau Laporan Realisasi Penerimaan APBD, (data diolah) }
\end{tabular}

Dari Tabel 2 dapat dilihat bahwa selama periode 3 tahun anggaran Kota Baubau realisasi penerimaan Pendapatan Asli Daerah (PAD) cenderung meningkat.Pada tahun 2014 pada pajak daerah cukup tinggiitu dilihat dari total Pendapatan Asli Daerah (PAD) Kota Baubau sebesar Rp. 56.050.485.189. Pada tahun 2015 total Pendapatan Asli Daerah (PAD) Kota Baubau mengalami penurunan yaitu sebesar Rp. 36.430.971.983. Pada Tahun 2016 Pendapatan Asli Daerah (PAD) Kota Baubau kembali mengalami peningkatan yaitu sebesar sebesar Rp. 43.540.205.382. 


\section{Pendapatan Pajak Daerah dan Target Penerimaan terhadap PAD Kota Baubau Tahun 2014 - 2016}

Tabel 3. Pendapatan Pajak Daerah dan Target Penerimaan terhadap PAD Kota Baubau Tahun 2014 - 2016

\begin{tabular}{|l|l|c|c|c|c|}
\hline No & $\begin{array}{c}\text { Tahun } \\
\text { Anggaran }\end{array}$ & $\begin{array}{c}\text { Realisasi Pajak } \\
\text { Daerah }\end{array}$ & PAD & $\begin{array}{c}\text { Pertumbuhan } \\
(\boldsymbol{\%})\end{array}$ & $\begin{array}{c}\text { Kontribusi } \\
(\boldsymbol{\%})\end{array}$ \\
\hline 1 & 2014 & 11.438 .566 .186 & 56.050 .485 .189 & $41,57 \%$ & $20,41 \%$ \\
\hline 2 & 2015 & 13.389 .629 .039 & 36.430 .971 .983 & $14,57 \%$ & $36,75 \%$ \\
\hline 3 & 2016 & 18.387 .214 .641 & 43.540 .205 .382 & $27,18 \%$ & $42,23 \%$ \\
\hline
\end{tabular}

Sumber :Dinas Pendapatan Daerah Kota Baubau Laporan Realisasi Penerimaan APBD, (data diolah)

Berdasarkan Tabel 3 di atas bahwa dalam menentukan target penerimaan dari pajak daerah lebih didasarkan pada kaidah inkremental (dinaikkan sekian \% dari tahun lalu), atau dengan menggunakan perkiraan, Perkiraan target tersebut sebenarnya tidak melihat potensi penerimaan sebenarnya yang ada pada masyarakat. Potensi penerimaan daerah untuk masing-masing jenis pajak daerah belum dihitung secara menyeluruh. Berdasarkan Tabel 3 di atas juga terlihat bahwa setiap tahunnya antara realisasi dan target terjadi selisih perkiraan yang berbeda dimana terkadang realisasi melampaui target dan terkadang sebaliknya. Belum adanya perubahan yang signifikan terhadap peningkatan PAD sampai saat ini (khususnya pajak daerah) disebabkan antara lain oleh ketidakmampuan daerah dalam membuat strategi koleksi dan memetakan potensi pajak daerah. Teknik yang digunakan untuk mengukur potensi seringkali tidak realistis yakni hanya didasarkan pada keinginan untuk senantiasa menaikkan pajak daerah, itupun dengan estimasi yang seringkali tidak akurat tanpa melihat aspek lain yang mempengaruhi keputusan tersebut.

\section{b. Pembahasan}

\section{1) Pertumbuhan Penerimaan Pajak berdasarkan Jenisnya}

Pemerintah Kota Baubau sampai dengan saat ini mengelola sembilan jenis pajak daerah yaitu; pajak hotel, pajak restoran, pajak hiburan, pajak reklame, pajak penerangan jalan, pajak mineral bukan logam dan batuan, bea perolehan hak atas tanah dan bangunan, pajak bumi dan bangunan (PBB) dan pajak parkir. Berbagai jenis pajak di atas dapat dijadikan indikator tingkat pertumbuhan pendapatan daerah di Kota Baubau yang dipengaruhi oleh setiap jenis pajak tersebut, hal ini dapat dilihat pada Tabel 4 berikut ini : 
Tabel 4.Rata-rata Pertumbuhan Penerimaan Pajak berdasarkan Jenis Pajak Daerah Kota Baubau, Tahun 2014 - 2016 (dalam \%)

\begin{tabular}{|c|c|c|c|c|c|}
\hline \multirow[t]{2}{*}{ No } & \multirow[t]{2}{*}{ Jenis Pajak Daerah } & \multicolumn{3}{|c|}{ Tahun Anggaran } & \multirow{2}{*}{$\begin{array}{c}\text { Rata- } \\
\text { Rata }(\%)\end{array}$} \\
\hline & & 2014 & 2015 & 2016 & \\
\hline 1 & Pajak Hotel & 16,86 & 27,13 & 17,48 & 20,49 \\
\hline 2 & Pajak Restoran & 54,58 & 27,00 & 160,32 & 80,63 \\
\hline 3 & Pajak Hiburan & 55,00 & 20,45 & 382,66 & 152,70 \\
\hline 4 & Pajak Reklame & 22,01 & 2,08 & 20,55 & 44,64 \\
\hline 5 & Pajak Penerangan Jalan & 13,10 & 12,51 & 15,23 & 13,61 \\
\hline 6 & $\begin{array}{l}\text { Pajak Mineral Bukan Logam dan } \\
\text { Batuan }\end{array}$ & 65,94 & $(5,73)$ & 0 & 20,07 \\
\hline 7 & $\begin{array}{l}\text { Bea Perolehan Hak Atas Tanah } \\
\text { dan Bangunan }\end{array}$ & 3,51 & $(3,68)$ & 50,10 & 16,64 \\
\hline 8 & $\begin{array}{l}\text { Pajak Bumi dan Bangunan } \\
\text { (PBB) }\end{array}$ & 0 & 27,48 & 11,28 & 19,38 \\
\hline 9 & Pajak Parkir & 0 & $1.571,6$ & 124,27 & 847,94 \\
\hline
\end{tabular}

Berdasarkan Tabel 4 terlihat bahwa setiap jenis pajak daerah Kota Baubau mengalami pertumbuhan yang sangat variatif. Pertumbuhan setiap pajak daerah dari tiga tahun pengamatan periode tahun 2014 sampai dengan 2016 dengan nilai rata-rata mulai dari yang terbesar sampai dengan yang terkecil adalah; pajak parkir $(847,94 \%)$, pajak hiburan (152,70), pajak restoran $(80,63 \%)$, pajak reklame $(44,64 \%)$, pajak hotel $(20,49 \%)$, pajak mineral bukan logam dan batuan $(20,07 \%)$, pajak bumi dan bangunan $(19,38 \%)$, bea perolehan hak atas tanah dan bangunan $(16,64 \%)$, pajak penerangan jalan $(13,61 \%)$.

\section{2) Kontribusi Jenis Pajak Daerah}

\section{Kontribusi Jenis Pajak Daerah terhadap Total Pajak Daerah}

Kontribusi setiap jenis pajak daerah akan membawa pengaruh terhadap total pendapatan pajak daerah, yang pada akhirnya akan membawa pengaruh kepada total pendapatan asli daerah. Berdasarkan hal tersebut dapat dilihat pada Tabel 5 berikut ini: 
Tabel 5. Rata-rata Kontribusi Jenis Pajak Daerah Terhadap Total Pajak Daerah Kota Baubau, 2014 - 2016 (dalam \%)

\begin{tabular}{|l|l|c|c|c|c|}
\hline \multirow{2}{*}{ No } & \multicolumn{1}{|c|}{ Jenis Pajak Daerah } & \multicolumn{3}{c|}{ Tahun Anggaran } & Rata- \\
\cline { 3 - 5 } & & $\mathbf{2 0 1 4}$ & $\mathbf{2 0 1 5}$ & $\mathbf{2 0 1 6}$ & Rata (\%) \\
\hline 1 & Pajak Hotel & 2,53 & 2,75 & 2,35 & 2,54 \\
\hline 2 & Pajak Restoran & 7,66 & 8,31 & 15,75 & 10,57 \\
\hline 3 & Pajak Hiburan & 1,39 & 1,43 & 5,01 & 2,61 \\
\hline 4 & Pajak Reklame & 5,53 & 4,82 & 4,23 & 4,86 \\
\hline 5 & Pajak Penerangan Jalan & 44,10 & 43,07 & 36,14 & 41,10 \\
\hline 6 & Pajak Mineral Bukan Logam dan Batuan & 0.38 & 0,04 & - & 0,14 \\
\hline 7 & Bea Perolehan Hak Atas Tanah dan & 17,30 & 14,56 & 15,59 & 15,82 \\
& Bangunan & & & & \\
\hline 8 & Pajak Bumi dan Bangunan (PBB) & 21,07 & 24,82 & 20,12 & 22,00 \\
\hline 9 & Pajak Parkir & 0,03 & 0,50 & 0,82 & 0,45 \\
\hline
\end{tabular}

Sumber :Dinas Pendapatan Daerah Kota Baubau (data diolah)

Berdasarkan Tabel 4 terlihat kontribusi setiap jenis pajak daerah terhadap total pajak daerah sangat bervariasi. Kontribusi rata-rata setiap jenis pajak daerah tiga tahun pengamatan yaitu periode dari tahun 2014 sampai dengan 2016 mulai dari yang terbesar sampai dengan yang terkecil adalah; pajak penerangan jalan (41,10\%), pajak PBB (22,00\%) pajak BPHTB (15,82\%), pajak restoran (10,57\%), pajak reklame $(4,86 \%)$, pajak hiburan $(2,61 \%)$, pajak hotel $(2,54 \%)$, pajak parkir $(0,45 \%)$ pajak mineral bukan logam dan batuan $(0,14 \%)$.

Kontribusi terbesar diberikan pajak penerangan jalan disebabkan besarnya nilai realisasi dibandingkan pajak-pajak daerah lainnya. Kontribusi terendah berdasarkan data di atas adalah pajak air tanah. Rendahnya kontribusi pajak air tanah ini disebabkan sistem pemungutan pajak air tanah menggunakan sistem self assessment dimana pendapatan dari hasil pajak berasal dari data dan penghitungan sendiri oleh wajib pajak, hal ini sangat memerlukan kejujuran dan kesadaran yang tinggi oleh wajib pajak untuk menentukan dan membayar pajaknya sehingga menyebabkan nilai kontribusi terhadap pendapatan sangat rendah.

\section{Kontribusi Jenis Pajak Daerah terhadap total Pendapatan Asli Daerah (PAD)}

Berdasarkan uraian di atas maka kontribusi jenis pajak daerah akan berpengaruh kontribusinya terhadap total pendapatan asli daerah. Selanjutnya untuk melihat seberapa besar kontribusi setiap jenis pajak daerah terhadap total pendapatan asli daerah di Kota Baubau dapat di lihat pada Tabel 6 berikut ini: 
Tabel 6. Rata-rata Kontribusi Jenis Pajak Daerah Terhadap PAD Kota Baubau 2014 s.d 2016 (dalam \%)

\begin{tabular}{|c|c|c|c|c|c|}
\hline \multirow[t]{2}{*}{ No } & \multirow[t]{2}{*}{ Jenis Pajak Daerah } & \multicolumn{3}{|c|}{ Tahun Anggaran } & \multirow{2}{*}{$\begin{array}{c}\text { Rata- } \\
\text { Rata } \\
(\%)\end{array}$} \\
\hline & & 2014 & 2015 & 2016 & \\
\hline 1 & Pajak Hotel & 0,58 & 1,00 & 9,93 & 3,84 \\
\hline 2 & Pajak Restoran & 1,56 & 3,05 & 6,65 & 3,75 \\
\hline 3 & Pajak Hiburan & 0,28 & 0,52 & 2,12 & 0,97 \\
\hline 4 & Pajak Reklame & 1,13 & 1,77 & 1,79 & 1,56 \\
\hline 5 & Pajak Penerangan Jalan & 9,00 & 15,83 & 15,26 & 13,36 \\
\hline 6 & $\begin{array}{l}\text { Pajak Mineral Bukan Logam dan } \\
\text { Batuan }\end{array}$ & 0,07 & 0,001 & - & 0,02 \\
\hline 7 & $\begin{array}{l}\text { Bea Perolehan Hak Atas Tanah } \\
\text { dan Bangunan }\end{array}$ & 3,53 & 5,24 & 6,58 & 5,12 \\
\hline 8 & Pajak Bumi dan Bangunan (PBB) & 4,30 & 9,12 & 8,50 & 7,31 \\
\hline 9 & Pajak Parkir & 0,007 & 1,83 & 3,44 & 1,76 \\
\hline
\end{tabular}

Dari Tabel 6 dapat dilihat bahwa pajak penerangan jalan memberikan kontribusi terbesar terhadap total pendapatan asli daerah. Jenis pajak daerah di Kota Baubau berdasarkan rata-rata selama tiga tahun pengamatan yaitu pada periode tahun 2014 sampai dengan 2016 terhadap jenis pajak yang secaraberturut-turut memberikan kontribusi dari yang terbesar sampai dengan yang terkecil terhadap total pendapatan asli daerah Kota Baubau adalah; pajak penerangan jalan (13,36\%), pajak PBB (7,31\%)pajak BPHTB $(5,12 \%)$, pajak hotel $(3,84 \%)$, pajak restoran $(3,75 \%)$, pajak parkir $(1,76 \%)$, pajak reklame $(1,56 \%)$, pajak hiburan $(0,97 \%)$ dan pajak mineral bukan logam $(0,02 \%)$.

\section{Identifikasi Jenis Pajak Daerah}

Untuk melakukan identifikasi terhadap pajak daerah di Kota Baubau digunakan rumus matrik berdasarkan alat analisis overlay. Perhitungan analisis overlay ini menggunakan rata-rata pertumbuhan pajak daerah pertahun selama 3 tahun yaitu dari tahun anggaran 2014 sampai dengan tahun anggaran 2016. Penggunaan perhitungan rata-rata pertumbuhan pertahun selama 3 tahun tersebut dilakukan untuk menyesuaikan dengan data yang dipergunakan dalam analisis overlay. Berdasarkan perhitungan terhadap setiap jenis pajak daerah dapat diidentikasi melalui klasifikasi terlihat pada Tabel 7 berikut ini: 
Tabel 7. Klasifikasi Jenis Pajak Daerah Kota Baubau Tahun 2014 - 2016

\begin{tabular}{|l|l|c|c|c|}
\hline \multirow{2}{*}{ No } & \multicolumn{1}{|c|}{ Jenis Pajak Daerah } & \multicolumn{3}{c|}{ KLASIFIKASI } \\
\cline { 3 - 5 } & & $\mathbf{2 0 1 4}$ & $\mathbf{2 0 1 5}$ & $\mathbf{2 0 1 6}$ \\
\hline 1 & Pajak Hotel & Prima & Prima & Prima \\
\hline 2 & Pajak Restoran & Prima & Prima & Prima \\
\hline 3 & Pajak Hiburan & Berkembang & Prima & Prima \\
\hline 4 & Pajak Reklame & Prima & Prima & Prima \\
\hline 5 & Pajak Penerangan Jalan & Prima & Prima & Prima \\
\hline 6 & $\begin{array}{l}\text { Pajak Mineral Bukan Logam dan } \\
\text { Batuan }\end{array}$ & Berkembang & Terbelakang & Terbelakang \\
\hline 7 & $\begin{array}{l}\text { Bea Perolehan Hak Atas Tanah dan } \\
\text { Bangunan }\end{array}$ & Prima & Potensial & Prima \\
\hline 8 & Pajak Bumi dan Bangunan (PBB) & Prima & Prima & Prima \\
\hline 9 & Pajak Parkir & Prima & Berkembang & Berkembang \\
\hline
\end{tabular}

Sumber :Dinas Pendapatan Daerah Kota Baubau Laporan Realisasi Penerimaan APBD, (data diolah)

Dari Tabel 7 di atas dapat dilihat bahwa klasifikasi jenis pajak daerah Kota Baubau tahun 2014 yang masuk kategori prima yaitu pajak hotel, pajak restoran, pajak reklame, pajak penerangan jalan, pajak hak atas tanah dan bangunan, pajak bumi dan bangunan (PBB) dan pajak parkir. Sedangkan yang masuk kategori berkembang yaitu pajak hiburan danpajak mineral bukan logam dan batuan. Pada tahun 2015 yang masuk kategori prima yaitu pajak hotel, pajak hiburan, pajak restoran, pajak reklame, pajak penerangan jalan dan pajak bumi dan bangunan (PBB). Sedangkan yang masuk kategori berkembang yaitu pajak parkir sedangkan kategori terbelakang yaitu pajak mineral bukan logam dan batuan sedangkan masuk kategori potensial terdapat pada bea perolehan hak atas tanah dan bangunan. Pada tahun 2016 yang masuk kategori prima yaitu pajak hotel, pajak hiburan, pajak restoran, pajak reklame, pajak penerangan jalan, bea perolehan hak atas tanah dan bangunan dan pajak bumi dan bangunan (PBB). Sedangkan yang masuk kategori berkembang yaitu pajak parkir sedangkan kategori terbelakang yaitu pajak mineral bukan logam dan batuan karena pertumbuhan dan kontribusi $\leq 1$. 


\section{KESIMPULAN}

Adapun kesimpulan dalam penulisan skripsi ini adalah sebagai berikut yaitu untuk tahun 2014 yang masuk kategori prima yaitu pajak hotel, pajak restoran, pajak reklame, pajak penerangan jalan, bea perolehan hak atas tanah dan bangunan dan pajak bumi dan bangunan (PBB). Dan kategori berkembang yaitu pajak hiburan dan pajak mineral bukan logam dan batuan. Sedangkan tahun 2015 yang masuk kategori prima yaitu pajak hotel, pajak restoran, pajak reklame, pajak hiburan, pajak penerangan jalan dan pajak bumi dan bangunan (PBB). Dan kategori berkembang yaitu pajak parkiran. Dan kategori terbelakang yaitu pajak mineral bukan logam dan batuan. Dan kategori potensial yaitu bea perolehan hak atas tanah dan bangunan. Sedangkan untuk tahun 2016 yang masuk kategori prima yaitu pajak hotel, pajak restoran, pajak reklame, pajak penerangan jalan, bea perolehan hak atas tanah dan bangunan dan pajak bumi dan bangunan (PBB). Dan kategori berkembang yaitu pajak parkir sedangkan kategori terbelakang yaitu pajak mineral bukan logam dan batuan karena pertumbuhan dan kontribusi $\leq 1$.

\section{SARAN}

Adapun saran yang diberikan penulis untuk Dinas Pendapatan Kota Baubau adalah:(1) optimalisasi pada pajak potensial untuk meningkatkan Pendapatan Asli Daerah (PAD) Kota Baubau; (2) melalui pendapatan atas entitas objek pajak jangan sampai ada kebocoran sehigga mengakibatkan kerugian pajak daerah yang mengakibatkan berkurangnya Pendapatan Asli Daerah (PAD) Kota Baubau; dan (3) dari hasil perhitungan analisis overlay dapat diketahui pertumbuhan dan kontribusi jenis pajak daerah di Kota Baubau sebagian besar teridentifikasi berkembang dan terbelakang. Hal ini perlu dilakukan peningkatan menjadi pajak daerah yang prima atau potensial. Peningkatan untuk yang berkembang dilakukan peningkatan kontribusi terhadap total pendapatannya seiring dengan tingkat pertumbuhan total pendapatan masing-masing jenis pajak daerah. Peningkatan untuk yang terbelakang melalui peningkatan pertumbuhan dan kontribusi seiring dengan peningkatan total pendapatan masing-masing jenis pajak daerah.

\section{DAFTAR PUSTAKA}

[1] Suwarno, 2008. Inovasi di Sektor Publik. Jakarta: STIA LAN.

[2] Wahyuni dan Adi, Priyo Hari.2009. Analisis Pertumbuhan dan Kontribusi Dana Bagi Hasil Terhadap Pendapatan Asli Daerah (Studi Pada Kabupaten/Kota se Jawa-Bali). The 3rd National Conference UKWMS, Page 1, Surabaya. 
[3] Kuncoro, Haryo, 2007. Fenomena Flypaper Effect pada Kinerja Keuangan Pemerintah Daerah Kota dan Kabupaten di Indonesia. Jurnal Ekonomi Pembangunan, Vol. 9. No. 1.Hal.47-63.

[4] Tim Gabungan LPEM-FEUI, Bappenas, NRM, dan BPPT. 2000. Penerimaan Daerah Dari Bagi Hasil Sumber Daya Alam (bagian akhir dari dua tulisan). Diakses pada $\quad 4 \quad$ Juni $2017 \quad$ dari https://www.bappenas.go.id/files/5413/5270/1901/raksasa_20091015140033_23 75_0.pdf

[5] Republik Indonesia. Undang-Undang Nomor 33 Tahun 2004 tentang Perimbangan Keuangan antara Pemerintah Pusat dan Pemerintahan Daerah.

[6] Handoko P, Sri, 2013. Analisis Tingkat Efektivitas Pajak Daerah Sebagai Sumber Pendapatan Asli Daerah Kota Pontianak, diakses pada tanggal 7 November 2013.

[7] Hartoyo, Nafsi. 2014. Optimalisasi PAD untuk Peningkatan Kinerja PEMDA. $\begin{array}{lllll}\text { Diakses } & \text { pada } & 4 & \text { Juni } & 2017\end{array}$ https://bppk.kemenkeu.go.id/id/publikasi/artikel/417-artikel-perimbangankeuangan/19684-optimalisasi-pad-untuk-peningkatan-kinerja-pemda

[8] Nur Annisa, 2013. Analisis Overlay Untuk Pembuatan Peta Tingkat Bahaya Erosi Wilayah DAS Cimandiri Pada Kabupaten Sukabumi, Universitas Pendidikan Indonesia.

[9] Sekaran, Uma. 2011. Metode Penelitian untuk Bisnis. Jakarta: Salemba Empat.

[10] Sugiyono, 2010. Statistik untuk Pendidikan, Bandung: Alfabeta, 2010.

[11] Sekaran, Uma. (2011). Research Methods for business Edisi I and 2. Jakarta: Salemba Empat

[12] Sugiyono 2010. Memahami Penelitian Kuantitatif Kualitatif \& RND, Bandung: Alfabeta.

[13] Jaya, W. K. 1996. Analisa Keuangan Daerah; Pendekatan Makro, Model Program PMSES, Kerjasama Ditjrn PUOD Depdagri dengan Pusat Penelitian dan Pengkajian Ekonomi dan Bisnis, Yogyakarta:UGM.

[14] Halim, Abdul, 2012. Manajemen Keuangan Sektor Publik. Jakarta : Salemba Empat

[15] Halim, Abdul. 2010. Seri Bunga Rampai Manajemen Keuangan Daerah. Yogyakarta : Unit Penerbitan dan Percetakan (UPP) AMP YKPN. 